\title{
Effectiveness of Teaching Materials of History to Improve the Political Awareness at SMA Katolik Diponegoro Blitar, Indonesia
}

\author{
Jeffry Dwi Kurniawan ${ }^{1}$, Muhammad Akhyar ${ }^{2}$, Susanto ${ }^{3}$
}

\begin{tabular}{l} 
ARTICLE INFO \\
\hline Article History: \\
Received 03.03.2019 \\
Received in revised form \\
10.06.2019. \\
Accepted \\
Available online $\mathbf{0 1 . 1 0 . 2 0 1 9}$
\end{tabular}

Available online 01.10.2019

\begin{abstract}
This study aimed to find out the effectiveness of teaching materials of the struggle of Todung Sutan Gunung Mulia to improve the students' political awareness. This study was conducted in class XI of Specialization in Linguistics, Sciences, and Social Sciences for the Indonesian history subject at SMA Katolik Diponegoro Blitar. The approach used in this research was the quasi-experimental approach with the pretest posttest control group design. The population and sample in this research were determined using the random sampling technique. The techniques of analyzing data used in this research were normality test, homogeneity test, mean similarity test and effectiveness test. The result of the research showed that the students who learned the history using the teaching materials of the struggle of Todung Sutan Gunung Mulia had the higher political awareness if compared to the students who were not provided with the treatment (the lecture method). This could be proven that there was a positive and significant improvement after the students were provided by the treatment in the experimental classroom. The average score of the students' political awareness which was initially 160.56 increased to 177.64 , while the average score in the control classroom did not have a positive and significant improvement. The average score of the students' political awareness which was initially 163.24 increased to 174.80 . The increased score of the political awareness in the control classroom was not significant if compared to the experimental classroom.
\end{abstract}

(c) IJERE. All rights reserved

Keywords:

Teaching Materials, Todung Sutan Gunung Mulia, Students' Political Awareness.

\section{INTRODUCTION}

SMAK Diponegoro Blitar is the only one Catholic senior high school in Blitar town, Indonesia in which Catholicity has the motto of pro ecclesia et patria which means that the people are required to be more sensitive to the conditions of the surrounding social politics for the sake of the state and the church. However, in the initial research conducted on December $3-4,2018$, the researcher found that the students thought that politics was dirty and needed to be avoided. They also did not have any interest in joining the governer election although they have already become the beginner voters (Interview with Celine, a student of class XI of Specialization in Linguistics and Gabriel, a student of class XI of Specialization in Sciences 1). On the other hand, the result of the interview with the history teacher showed that the teachers considered that politics was dirty, justified all ways, corruption and ended up in prison. In addition, the teacher did not understand that teaching history was teaching about politics (Interview with Mr. Anton and Mrs. Hera as the History Teachers). This showed that the students' political awareness at SMA Katolik Diponegoro Blitar was still low.

Political awareness is related to the level of educational achievement and socio-economic position in the society (Almond \& Verba, 1990: 70) because the level of education is influential to reduce economic problems, especially the problem of unemployment (Hindun, 2019). Therefore, the well-educated people were more aware of the government's influence on their lives so that they paid more attention to the politics and searched much information about the political process (Almond \& Powell, 1978: 47). The

\footnotetext{
1 jeffrydwikurniawan@student.uns.ac.id, orcid.org/ 0000-0002-7649-5148

2 makhaliya@yahoo.com, orcid.org/0000-0001-9176-1371

3 susantofibuns@staff.uns.ac.id, orcid.org/0000-0003-0897-1592
} 
political awareness can be built through the critical dialogues in the history classroom because history can be used as the political education to introduce the state ideology as well as the rights and obligations (Kuntowijoyo, 2013: 22).

In the $21^{\text {st }}$ century, the learning paradigm changed from behavioristic to constructivist (Sayono, 2013). In learning history, teachers are required to teach higher order thinking skills (Collins, 2014) and have skills of Communication, Critical Thinking, Collaborative, and Creativity (Saavedra \& Darleen Opfer, 2012). This is in line with Kuntowijoyo (2013: 4) who stated that the history learning at SMA should be critically taught because the students has been able to think critically.

In teaching history, a textbook is one of the important teaching aids because it contains the extensive materials (Ahmad, 2013). However, most teachers use the textbook as the standard in the teaching. According to Prastowo (2012), a number of teachers used conventional textbooks without having the process of planning, preparing, and managing the efforts of individuals. As the result, the use of textbooks would be ineffective, monotonous, and not make the students think critically.

In the basic competencies of 3.6 of the Indonesian history materials, there was analyzing the roles of the national and local figures in fighting for the Indonesian independence. İronically, the government textbooks only showed one story of the participation of Christianity that was involved in the national movement. This was on page 190 containing "from the Christian youth, Association of Christian Youth Movement was established and from the Catholic youth, Young Catholic was established." The researcher thought that this was not relevant between the government textbooks and the conditions needed by the students at SMAK Diponegoro Blitar. Thus, the researcher developed the history teaching materials of the struggle of Todung Sutan Gunung Mulia.

Todung Sutan Gunung Mulia was chosen by the researcher because of his roles in fighting for the Indonesian independence starting from becoming the member of the Volksraad, the editor of the magazine of Zaman Baru, the member of Christelijk Ethische Partij, the initiator of the Indonesian Christian Party, the Second Minister of Education, the founder of the Indonesian church council, the founder of the Indonesian biblical institution, the founder of Indonesian Christian University, and his name was enshrined in the Christian publishing board, namely BPK Gunung Mulia (Simatupang, 1985: 26-27; Klinken, 2010: 99-107). The history learning using the teaching materials of the struggle of Todung Sutan Gunung Mulia was focused to improve the students' political awareness. Therefore, the lack of the students' political awareness could be overcome using the development of the teaching materials.

\section{Situation of Problem}

Based on the explanation above, the problem in this research was "Was there a positive and significant influence using the teaching materials of the struggle of Todung Sutan Gunung Mulia on the improvement of the students' political awareness?"

Aim of the Study

This study aimed to test the effectiveness of the teaching materials of the struggle of Todung Sutan Gunung Mulia to improve the students' political awareness at SMA Katolik Diponegoro Blitar.

\section{METHOD}

This research used the quasi experiment in which the quasi experiment is a research to find out whether there is a result of the treatment on the investigated subject. The way to find out is by comparing one or more experimental groups given the treatment with one comparison group that is not given the treatment (Arikunto, 2016). The population of this research was all students of class XI at SMA Katolik Diponegoro Blitar, Indonesia year 2018-2019. There were five classrooms, namely class XI of specialization in Linguistics, XI of specialization in Sciences 1 and 2, as well as XI of specialization in Social Sciences 1 and 2 in which the students of those classrooms joined the Indonesian history subject. 
Kurniawan ,J.D., Akhyar ,M. \& Susanto(2019).Effectiveness of teaching materials of history to improve the political awareness at SMA Katolik Diponegoro Blitar, Indonesia. International Journal of Educational Research Review,4(4),536-542.

From these classrooms of XI, there would be two classrooms, namely the experimental classroom and the control classroom.

Each experimental classroom and control classroom have male and female students. On average, they were 17-18 year old Christian and Catholic students. In addition, they come from various tribes and regions in Indonesia, such as Nias, North Sumatra (Batak), Javanese, Chinese, Balinese, Kalimantan (Dayak), Manado, and Papua. The experimental classroom consisted of 8 students of class XI of Specialization in Linguistics, 17 students of class XI of Specialization in Sciences 1 and 20 students of class XI of Specialization in Social Sciences 1 in which those students would be given the treatment in the form of providing the teaching materials of the struggle of Todung Sutan Gunung Mulia with the help of the jurisprudential inquiry model. On the other hand, the control classroom consisted of 8 students of class XI of Specialization in Linguistics, 17 students of class XI of Specialization in Sciences 2 and 20 students of class XI of Specialization in Social Sciences 2 with the lecture method (without the treatment). The techniques of collecting data in this research were interview and questionnaire about the political awareness. The question analysis started from the trial using the product moment validity and the reliability test using Cronbach's alpha. Then, the prerequisite test was conducted first with the normality test, homogeneity test, mean similarity test and effectiveness test.

\section{Material}

The questionnaire about the political awareness had been created using the Likert scale 1-5 with 50 items which were then tested for the validity and the realibity using SPSS 24 . Here are the examples of the items that had been tested:

1. I feel concerned when there is persecution of people who have different opinions

2. I feel concerned when religion is used as a political tool

3. I must follow political developments in Indonesia

4. I feel proud to choose the leaders of sons of the soil

5. I assume that youth organizations are not important

In the calculation of the validity, if the significant value (2-tailed) was $<0.05$ and the pearson correlation was positive, the item of the questionnaire was valid. Based on the table of the results of the validity test of the 50 items, there were 40 valid items and 10 invalid items. Thus, in the pretest and posttest, the researcher used the 40 valid items. On the other hand, the result of the reliability test was 0.971 because Cronbach's alpha was $0.971>0.60$. Thus, the questionnaire for the test of the political awareness was reliable.

\section{Data Analysis}

This research used SPSS 24 to analyze the data. The scales used in every item of the political awareness were (5) Strongly Agree, (4) Agree, (3) Undecided, (2) Disagree, (1) Strongly Disagree, while the negative items were reversed before being analyzed. The hypotheses of this research were below.

1) Hypothesis

$\mathrm{H}_{0} \quad=$ There was no difference between the average improvement of the students' positive and significant political awareness in the experimental classroom and the control classroom after given the treatment (the use of the teaching materials)

$\mathrm{H}_{1}=$ The was difference between the average improvement of the students' positive and significant political awareness in the experimental classroom and the control classroom after given the treatment (the use of the teaching materials)

2) The test used a two-sided test with a short significance of $\alpha=0.05$

3) The test decision 
$\mathrm{H}_{0}$ was accepted if the significance was $>0.05$

$\mathrm{H}_{0}$ was rejected if the significance was $>0.05$

\section{FINDINGS}

\section{Normality Test of the Experimental Classroom}

Based on the result of the normality test using SPSS 24, the results of the calculation can be seen in the table below.

\begin{tabular}{|c|c|c|c|c|c|}
\hline Category & $\begin{array}{l}\text { Kolmogorof } \\
\text { Smirnov }\end{array}$ & Sig & $\begin{array}{l}\text { Shapiro } \\
\text { Wilk }\end{array}$ & Sig & Conclusion \\
\hline Pretest & 0.080 & 0.200 & 0.970 & 0.288 & Normal \\
\hline Posttest & 0.089 & 0.200 & 0.970 & 0.290 & Normal \\
\hline
\end{tabular}

The statistical calculation showed that the significance was $>0.05$ so that the data was normally distributed. Based on the results of pretest and posttest in the table above, it can be concluded that the test of the political awareness in the experimental classroom was normally distributed.

\section{Normality Test of the Control Classroom}

Table $2 \quad$ Normality test of pretest and posttest of the questionnaire in the control classroom

\begin{tabular}{llllll}
\hline Category & $\begin{array}{l}\text { Kolmogorof } \\
\text { Smirnov }\end{array}$ & Sig & $\begin{array}{l}\text { Shapiro } \\
\text { Wilk }\end{array}$ & Sig & Conclusion \\
\hline Pretest & 0.106 & 0.200 & 0.968 & 0.242 & Normal \\
\hline Posttest & 0.083 & 0.200 & 0.982 & 0.698 & Normal \\
\hline
\end{tabular}

The statistical calculation showed that the significance was $>0.05$ so that the data was normally distributed. Based on the results of pretest and posttest in the table above, it can be concluded that the test of the political awareness in the control classroom was normally distributed.

\section{Homogeneity Test of the Control and Experimental Classroom}

The homogeneity test was the requirement to be able to conduct the $\mathrm{T}$ test. The results of the calculation using One-Way ANOVA can be seen in the table below.

Table $3 \quad$ Homogeneity test in the control and experimental classroom

\begin{tabular}{llllll}
\hline \multicolumn{2}{l}{ Test of Homogeneity of Variances } & \multicolumn{3}{l}{ Anova } \\
\hline Levene Statistic & df1 & df2 & Sig & F & Sig \\
\hline 1.534 & 1 & 88 & 0.219 & 4.054 & 0.047 \\
\hline
\end{tabular}

The data was homogeneous if the significance value was $>0.05$. Based on the results of the test of homogeneity of variances, it can be found out that the significance result and the homogeneity test result were 0.219 . This can be concluded that there was no difference of variances between the experimental classroom and the control classroom so that these classrooms were homogeneous.

\section{Equality Test and Difference Test}

The equality test before given the treatment (the control classroom and experimental classroom) was below. 
Table $4 \quad$ Equality test before given the treatment in the experimental classroom and the control classroom

\begin{tabular}{|c|c|c|c|c|c|}
\hline $\begin{array}{l}\text { Experimental } \\
\text { Classroom }\end{array}$ & Control Classroom & Test Re & & & \\
\hline $\begin{array}{l}\sum \\
\text { Students }\end{array}$ & $\begin{array}{l}\sum \\
\text { Students }\end{array}$ & $\mathrm{F}$ & Sig & $\mathrm{T}$ & Sig \\
\hline 160.56 & 163.24 & 1.534 & 0.219 & 2.013 & 0.047 \\
\hline
\end{tabular}

Based on the results of the statistical test with SPSS 24, the result of F test was 1.534 and the significance value was $0.219>0.05$ so that $\mathrm{H}_{0}$ was accepted. This means that the data variances between the experimental classroom and the control classroom were homogeneous or the same. On the other hand, the result of $\mathrm{T}$ test was 2.013 and the significance value was $0.047>0.05$ so that $\mathrm{H}_{0}$ was accepted. This means that there was no significant difference between the value of the experimental classroom and the control classroom.

The average difference test before and after given the treatment in the control classroom was below.

Table $5 \quad$ Average difference test before and after given the treatment in the control classroom

\begin{tabular}{llll}
\hline Average & & \multicolumn{2}{l}{ Test Results } \\
\hline Before & After & T & Sig \\
\hline 163.24 & 174.80 & 10.760 & 0.000 \\
\hline
\end{tabular}

Based on the results of the statistical test with SPSS 24, the results of the average test in the control classroom were 163.24 (before given the treatment) and 174.80 (after given the treatment), while the result of $\mathrm{T}$ test was 10.760 and the significance value was $0.000<0.05$. Thus, $\mathrm{H}_{0}$ was rejected so that the average values before and after given the treatment in the control classroom were not the same.

The average difference test before and after given the treatment in the experimental classroom was below. Table $6 \quad$ Average difference test before and after given the treatment in the experimental classroom

\begin{tabular}{cccc}
\hline Average & \multicolumn{3}{c}{ Test Results } \\
\hline Before & After & T & Sig \\
\hline 160.56 & 177.64 & 14.311 & 0.000 \\
\hline
\end{tabular}

Based on the results of the statistical test with SPSS 24, the results of the average test in the experimental classroom were 160.56 (before given the treatment) and 177.64 (after given the treatment), while the result of $\mathrm{T}$ test was 14.311 and the significance value was $0.000<0.05$. Thus, $\mathrm{H}_{0}$ was rejected so that the average values before and after given the treatment in the experimental classroom were not the same.

\section{Effectiveness Test of the Political Awareness}

Table $7 \quad$ Effectiveness test of the political awareness

\begin{tabular}{|c|c|c|c|c|c|c|}
\hline $\begin{array}{l}\text { Experimental } \\
\text { Classroom }\end{array}$ & Control Cla & room & Test Re & & & \\
\hline $\begin{array}{l}\sum \\
\text { Students }\end{array}$ & $\sum$ Students & Average & $\mathrm{F}$ & Sig & $\mathrm{T}$ & Sig \\
\hline 177.64 & 45 & 174.80 & 1.150 & 0.287 & 3.189 & 0.002 \\
\hline
\end{tabular}


Based on the results of the statistical test with SPSS 24, the result of F test was 1.150 and the significance value was $0.287>0.05$ so that there was equality of variances, while the result of $\mathrm{T}$ test was 3.189 and the significance value was $0.002<0.05$ so that $\mathrm{H}_{0}$ was rejected. Thus, there was difference of the average improvement of the students' positive and significant political awareness in the experimental classroom after given the treatment (the use of the teaching materials).

\section{DISCUSSION AND SUGGESTIONS}

Based on the conducted effectiveness test, it showed that there was an improvement of the students' political awareness through the history learning using the history teaching materials of the struggle of Todung Sutan Gunung Mulia. The result of the statistical test in the experimental classroom had a positive and significant improvement after given the treatment. The average score of the students' political awareness which was initially 160.56 increased to 177.64 . The average value of the result of the effectiveness test in the control group without giving the treatment did not have a positive and significant improvement. The average score of the students' political awareness which was initially 163.24 increased to 174.80 . The increased score of the political awareness in the control classroom was not significant if compared to the experimental classroom. Thus, it can be concluded that the effectiveness test of the history teaching materials of the struggle of Todung Sutan Gunung Mulia could fulfill the standard to be used in the history learning to improve the students' political awareness.

The result of this research was supported by the research conducted by Wiratma (2010). The research result of Wiratma showed that in an effort to direct the students to become the intelligent, critical, self-centered and humanistic humans, political education is needed to humanize humans through education policy. Fajar (2014) affirmed that education can become the media of political education to instill the political awareness to the generation of the nation through various political education programs, such as: civic education subject, history subject, Student Council activities, extracurricular activities and planned or incidental activities aiming to provide political information to the students. Besides, the use of the teaching materials can help the students to improve the political awareness like what had been conducted by Rohmadi and Rahmadhan (2019). The research result of Rohmadi and Rahmadhan showed that the use of the history module of Mohammad Husni Thamrin based on PBL was very effective to improve the students' political awareness. By using the history module, the students' political awareness was higher than the students that were taught using the lecture method. In addition, this teaching material was also used to improve the students' literacy skill through the program of (GLS) School Literacy Movement (Sihaloho, et al., 2019) and develop the teacher's idealism towards the process of teaching and learning activities in the classroom (Bahcuvanoglui, 2018).

This research was limited to the classrooms of XI at SMA Katolik Diponegoro Blitar, Indonesia year 2018-2019 and only measured the attitude (the students' political awareness). Therefore, the next researches can be developed at various levels of senior high schools like class $X$ and class XII. The researches can also test the effectiveness of the printed or electronic teaching materials in accordance with the facilities and infrastructure owned by the students and school. Furthermore, the teaching materials can be used to measure the students' achievements and other figures can also be used so that the scope of materials is more comprehensive. The researcher also hopes that this teaching material can keep being used both in the classroom and outside the classroom.

\section{REFERENCES}

Ahmad, A. R. (2013). The skills of using history textbooks in secondary school. Asian Social Science, 9(12), 229. 
Almond, G. A. \& Powell, Jr. GB. 1978. Komparative Politics, System, Process and Policy. Boston: Little Brown.

Almond, G. A. \& Verba, S. 1990. Budaya Politik: Tingkah Laku Politik dan Demokasi Lima Negara. Penerjemah Sahat Simamora. Jakarta: Bumi Aksara.

Arikunto, S. (2016). Prosedur Penelitian: Suatu Pendekatan Praktik. Jakarta: Rineka Cipta.

Bahcuvanoglui, F. F. (2018). Evaluation of teachers' views concerning ideality levels. International Journal of Educational Research Review, 3(1), 21-27.

Collins, R. (2014). Skill for the $21^{\text {st }}$ century: Teaching higher-order thinking. Curriculum $\mathcal{E}$ Leadership Journal: An electronic journal for leaders in education, 12(14).

Fajar, W. N. (2014). Pelaksanaan pendidikan politik di sekolah meningkatkan kesadaran politik siswa. Khazanah Pendidikan, 6(2).

Hindun. (2019). Impact of education level on unemployment rate in Indonesia. International Journal of Educational Research Review, 4(3), 321-324.

Klinken, G. V. (2010). 5 Penggerak Bangsa yang Terlupakan: Nasionalisme Minoritas Kristen. Amiruddin (Penerjemah). Yogyakarta: LKIS.

Kuntowijoyo. (2013). Pengantar Ilmu Sejarah. Yogyakarta: Tiara Wacana.

Prastowo, A. (2012). Panduan Kreatif Membuat Bahan Ajar Inovatif, Menciptakan Metode Pembelajaran yang Menarik dan Menyenangkan. Yogyakarta: DIVA Press.

Rohmadi, N. \& Ramadhan, I. R. (2019). Efektivitas modul pembelajaran sejarah Mohammad Husni Thamrin untuk meningkatkan kesadaran politik siswa. Jurnal Historia, 7(1), ISSN 2337-4713.

Saavedra, A. R. \& Opfer, V. D. (2012). Learning 21st-century skills requires 21st-century teaching. Phi Delta Kappan, 94(2), 8-13.

Sayono, J. (2013). Pembelajaran sejarah di sekolah: Dari pragmatis ke idealis. Jurnal Sejarah dan Budaya, (1), 9-17.

Sihaloho, F. A. S., Martono, T., \& Daerobi, A. (2019). The implementation of school literacy movement at the senior high school. International Journal of Educational Research Review, 4(1), 88-96.

Simatupang, T. B. (1985). Iman Kristen dan Pancasila. Jakarta: BPK Gunung Mulia.

Wiratma, I. G. L. (2010). Politik pendidikan dalam pengembangan kesadaran kritis dan jati diri. Jurnal Ika, 8(2), ISSN 1829-5282. 